\title{
Transformasi Nilai Pendidikan Islam Anak di PAUD Sultan Qaimuddin Kendari Pada Masa Pandemi Covid 19
}

\author{
Aris Try Andreas Putra ${ }^{1}$, Sufiani ${ }^{2}$, dan Jahada ${ }^{3}$ \\ 1,2 Program Studi PAI, FATIK, IAIN Kendari, ${ }^{3}$ FKIP, Universitas Halu Oleo \\ e-mail corresponden: aristryandreasputraaritonda@gmail.com
}

ABSTRAK. Pandemi Covid 19 merupakan sebuah masa dimana lembaga pendidikan termasuk PAUD melakukan penyesuaian terhadap kegiatan pembelajaran. Misalnya semula kegiatan pembelajaran dilakukan di sekolah, kini dilakuan di rumah. Semula kegiatan pembelajaran dilakukan melalui tatap muka, kini dilakukan tatap maya. Semula kegiatan pembelajaran dimediasi oleh guru, kini dimediasi oleh orang tua. Transformasi nilai pendidikan Islam secara sistematis yang semulanya dirancang oleh guru disekolah, kini dilakukan bersama-sama orang tua di rumah. Artikel ini bertujuan untuk menjelaskan dan menganalisis transformasi nilai pendidikan Islam anak di PAUD Sultan Qaimuddin Kendari pada masa pandemi Covid 19. Penelitian ini berjenis kualitatif dengan deskriptif analitis. Lokus penelitian ini di PAUD Sultan Qaimuddin Kendari, yang dilaksanakan pada bulan Mei sampai Juli 2020, dengan informan yaitu kepala sekolah, guru, dan orang tua. Hasil penelitian mengungkapkan 1) kegiatan transformasi nilai pendidikan Islam anak masih dilakukan dimasa pandemi covid 19, walaupun tidak semua nilai agama ditanamkan pada anak. 2) Proses transformasi nilai pendidikan Islam anak dilakukan oleh guru bersama orang tua melalui komunikasi online (whatsapp) mengalami hambatan, tidak seperti aktifitas tatap muka. 3) Nilai pendidikan Islam yang ditrasformasikan pada anak adalah nilai akidah, nilai akhlak dan nilai amaliyah.

Kata Kunci : Nilai Pendidikan Islam, Nilai Aqidah, Nilai Amaliyah, Anak PAUD

\begin{abstract}
Pandemic Covid 19 caused the condition of all educational institutions including PAUD to make adjustments to all learning activities. For example initially learning activities carried out at school, now carried out at home. Initially learning activities carried out through face to face, now online. Initially learning activities were facilitated by the teacher, now facilitated by parents. The systematic transformation of the value of Islamic education which was originally designed by teachers in schools is now being done together with parents at home. This article aims to explain and analyze the transformation of the value of Islamic education of children in PAUD Sultan Qaimuddin Kendari during the pandemic Covid 19. This research is a qualitative type with analytical descriptive. The locus of this research was at the Sultan Qaimuddin Kendari PAUD, which was conducted from May to July 2020, with informants head master, teachers and parents. The results revealed that 1) the transformation of children's Islamic educational values was still carried out in the pandemic covid 19 period, although not all religious values were instilled in children. 2) The process of transforming the value of Islamic education in children is done by teachers and parents through online communication (WhatsApp) experiencing obstacles, unlike face-to-face activities. 3) The value of Islamic education that is transformed in children is the value of faith, moral values and amaliyah values.
\end{abstract}

Keyword : Islamic Valuae, Aqidah Value, Amaliyah Value, early childhood 


\section{PENDAHULUAN}

Semua lembaga pendidikan dimasa pandemi covid 19 melakukan rekondisi dan redesain proses penyelenggaraan pendidikan, mulai lembaga pendidikan tinggi sampai pendidikan anak usia dini. Pendidikan anak usia dini merupakan sebuah program yang diselenggarakan dan ditujukan kepada anak sejak lahir sampai usia 6 (enam) tahun yang dilakukan melalui pemberian rancangan pendidikan untuk membantu pertumbuhan dan perkembangan jasmani dan rohani agar anak memiliki kesiapan dalam memasuki pendidikan lebih lanjut. Selanjutnya untuk memberikan pembinaan secara sistematik maka lembaga pendidikan menyelenggarakan satuan atau program PAUD. Satuan atau program PAUD merupakan layanan PAUD yang dilaksanakan pada suatu lembaga pendidikan dalam bentuk Taman Kanak-kanak (TK)/Raudatul Athfal (RA)/Bustanul Athfal (BA), Kelompok Bermain (KB), Taman Penitipan Anak (TPA), dan Satuan PAUD Sejenis (SPS). Dalam menyelenggarakan satuan atau program PAUD maka lembaga pendidikan berpedoman pada Standar Nasional Pendidikan Anak Usia Dini[1].

Permendikbud Nomor 137 Tahun 2014 tentang Standar Nasional Pendidikan Anak Usia Dini pada Pasal 1 ayat (2) dijelaskan tentang Standar Tingkat Pencapaian Perkembangan Anak Usia Dini. Dalam regulasi tersebut disebutkan terdapat enam aspek perkembangan dan pertumbuhan anak PAUD sebagai berikut: 1) nilai agama dan moral, 2) fisik-motorik, 3) kognitif, 4) bahasa, 5) social-emosional, 6) seni. Nilai Agama dan Moral seperti (mengenal dan meyakini agama anak, melaksanakan ibadah; membaca doa-doa, menghargai dan menghormati, menjaga kebersihan dan kesucian diri, mengetahui hari besar agama dan lainnya). Selanjutnya Fisik Motorik (a. Motorik kasar: mampu mengontrol gerak tubuh secara baik, seimbang, dan terkordinasi dengan baik, b. Motorik halus: mampu menggunakan alat-alat/instrument untuk mengeksperiskan dan menggali kemampuan diri, c. Kesehatan dan perilaku keselamatan: memiliki berat, tinggi badan, lingkar kepala, serta peduli pada kebersihan, kesehatan dan keselamatan). Kognitif (a. belajar dan pemecahan masalah, kemampuan memecahkan masalahmasalah dalam kegiatan harian, b. berpikir logis, kemampuan anak melakukan klasifikasi, kategorisasai, membedakan, memiliki rencana, memiliki inisiatif dan lainnya). Sosial Emosional (a. Kesadaran diri, mengenal diri sendiri, mengontrol diri, beradaptasi dengn orang lain, b. Tanggung jawab, mengetahui hak dan kewajiban, taat aturan, self regulating, responsibilias, c. perilaku prososial, bekerjasama dengan teman, memiliki rasa hormat dan kesantunan, memiliki sikap toleransi). Bahasa (a. Memahami bahasa, memahami cerita, memahami kata perintah, b.Mengekspresikan bahasa, mampu melakukan tanya jawab, mampu berkomunikasi, c. keaksaraan, memahami huruf, kata, bunyi, meniru bentuk huruf dan lainnya).

Standar tingkatan pencapaian perkembangan anak usia dini seperti yang telah ditetapkan di atas agaknya sulit untuk dicapai secara maksimal dimasa pandemi covid 19 ini. Standar proses PAUD kini disesuaikan dengan kondisi pandemi covid 19, kriteria tentang pelaksanaan pembelajaran pada satuan atau program PAUD dalam rangka membantu pemenuhan tingkat pencapaian perkembangan yang sesuai dengan tingkat usia anak juga memperhatikan kondisi pandemi. Begitupun standar penilaian, standar penilaian kriteria tentang penilaian proses dan hasil pembelajaran dalam rangka 
mengetahui tingkat pencapaian yang sesuai dengan tingkat usia anak dilakukan penyesuaian oleh guru PAUD. Tidak terkecuali standar sarana dan prasarana atau kriteria tentang persyaratan pendukung penyelenggaraan dan pengelolaan pendidikan anak usia dini secara holistik dan integratif yang memanfaatkan potensi lokal terhalang oleh kondisi pandemi covid 19. Standar proses dan hasil pencapaian anak usia dini jelas dilakukan redesain mengingat beberapa hal: pertama, pada rancangan awal sebelum covid 19 kegiatan pembelajaran dilakukan di sekolah, kini dilakuan di rumah. Kedua, kegiatan pembelajaran awalnya dilakukan melalui tatap muka, kini dilakukan tatap maya. Ketiga, kegiatan pembelajaran awalnya difasilitasi oleh guru secara optimal, kini difasilitasi oleh orang tua. Kondisi-kondisi tersebut membutuhkan adaptasi dari berbagai faktor yang terlibat dalam proses penyelenggaraan pendidikan.

Penelitian Wulandari misalnya mengungkapkan bahwa sistem pembelajaran online atau daring pada masa pandemi covid 19 ini memberikan pengaruh negatif terhadap pencapaian perkembangan anak usia dini di TK[2]. Hampir sebagian besar pencapaian perkembangan anak pada beberapa aspek selama pembelajaran daring mengalami penurunan. Tidak terkecuali kondisi PAUD Sultan Qaimuddin di Kota Kendari. Berdasarkan wawancara ditemukan informasi bahwa masa pandemi covid 19 memberikan dampak terhadap penyelenggaraan proses pembelajaran. Kriteria atau standar pendidikan anak usia dini berdasarkan aspek pertumbuhan dan perkembangan anak tidak tersentuh secara maksimal. Covid 19 juga menyebabkan guru dan orang tua melakukan kolaborasi dalam pembimbingan anak khususnya pada transformasi nilai pendidikan Islam. Penanaman nilai agama dan moral anak menjadi sesuatu yang tidak terlupakan oleh orang tua di rumah. (Wawancara, Mayani, 2020). Guru dan orang tua memainkan peran yang cukup penting dalam pembelajaran dimasa pandemi ini. Guru PAUD di sekolah melakukan dua tugas pokok sebagai guru yaitu perencana dan penilai hasil perkembangan anak usia dini sementara pendidik PAUD di rumah (orang tua) berfungsi sebagai pelaksana pembelajaran dengan memanfaatkan strategi diskusi (percapakan/tanya jawab) dan keteladanan[3].

Oleh karena itu, pada masa pandemi penulis memfokuskan pada bagaimana lembaga pendidikan anak usia dini menyelenggarakan pembelajaran, khususnya melakukan transformasi nilai pendidikan Islam pada anak. Kajian ini penting untuk dilakukan, karena di tengah pandemi covid 19, anak harus dikuatkan dengan penanaman nilai pendidikan Islam. Penanaman nilai menjadi turbin yang menggerakkan anak untuk memiliki pengalaman sejak dini, agar anak tumbuh menjadi pribadi-pribadi yang memiliki integritas moral, sehingga mereka bisa menyesuaikan diri dengan lingkungan dimana mereka hidup dan berkembang.

Tulisan tentang perkembangan nilai agama dan moral anak PAUD telah banyak dibahas oleh penulis sebelumnya, juga kajian tentang strategi pembelajaran anak pada masa pandemi covid 19 telah banyak mendapat perhatian. Seperti tulisan Kurniati tentang peran orang tua dimasa pandemi. Kurniati mengemukakan peran orang tua selama masa pandemi covid 19 adalah sebagai pembimbing, pendidik, penjaga, pengembang dan pengawas. Secara khusus peran yang muncul yaitu: menjaga dan memastikan anak untuk menerapkan hidup bersih dan sehat, mendampingi anak dalam 
mengerjakan tugas sekolah, melakukan kegiatan bersama selama di rumah, menciptakan lingkungan yang nyaman untuk anak, menjalin komunikasi yang intens dengan anak, bermain bersama anak, menjadi role model bagi anak, memberikan pengawasan pada anggota keluarga, menafkahi dan memenuhi kebutuhan keluarga, dan membimbing dan memotivasi anak, memberikan edukasi, memelihara nilai keagamaan, melakukan variasi dan inovasi kegiatan di rumah[4]. Namun kajian-kajian spesifik tentang trasformasi nilai pendidikan Islam anak PAUD khusunya dimasa pandemi covid 19 masih jarang ditemukan atau bahkan belum ditemukan. Oleh karena itu, tulisan ini mencoba menyajikan bagaimana guru PAUD mentrasformasikan nilai pendidikan Islam kepada anak dimasa pandemi covid 19. Dengan demikian tulisan ini dapat menjadi referensi bagi guru dan orang tua terhadap penguatan dan penanaman nilai pendidikan Islam pada anak dalam situasi apapun juga, termasuk dimasa pandemi ini.

Tulisan ini berdiri di atas konsep-konsep yang berhubungan dengan konsep nilai, konsep pendidikan Islam dan konsep tentang fungsi nilai. Menurut Rokeach dan Bank, sebagaimana yang dikutip Thoha, bahwa "nilai adalah suatu kepercayaan yang berada dalam ruang lingkup kepercayaan, di mana seseorang harus bertindak atau menjauhi suatu perilaku mengenai sesuatu yang pantas atau tidak untuk dilakukan"[5]. Nilai-nilai adalah pedoman atau landasan bagi sebuah perubahan. Nilai sebagai sesuatu yang abstrak yang mempunyai fungsi-fungsi tertentu sebagai berikut: 1) Nilai memberi tujuan atau arah (goals of purpose) kemana harus dituju, 2) Nilai memberi aspirasi (aspirations) atau inspirasi kepada seseorang untuk hal yang berguna, baik, dan positif bagi kehidupan, 3) Nilai mengantar seseorang untuk bertingkah laku (attitudes), 4) Nilai itu menarik (interests), 5) Nilai itu mempengaruhi perasaan (feelings), 6) Nilai bertalian dengan keyakinan atau kepercayaan (beliefs and convictions), 7) Nilai menghendaki aktivitas (activities), dan 8) Nilai muncul dalam kesadaran[6].

Selanjutnya Yusuf Qardawi menjelaskan pendidikan Islam adalah pendidikan manusia seutuhnya, akal dan hatinya, rohani dan jasmaninya, akhlak dan keterampilannya. Karena itu pendidikan Islam menyiapkan manusia untuk hidup baik dalam keadaan damai maupun perang, dan menyiapkannya untuk menghadapi masyarakat dengan segala kebaikan dan kejahatannya, manis dan pahitnya[7]. Selanjutnya Hasan Langgulung mendefinisikan pendidikan Islam merupakan suatu proses penyiapan generasi muda untuk mengisi peranan, memindahkan pengetahuan dan nilai-nilai Islam yang diselaraskan dengan fungsi manusia untuk beramal di dunia dan memetik hasilnya di akhirat[8]. Abuddin Nata mengatakan bahwa "Pendidikan Islam adalah pendidikan yang didasarkan pada nilai-nilai ajaran Islam sebagaimana yang tercantum dalam al-Qur'an dan al-Hadits serta dalam pemikiran para ulama dan dalam praktek sejarah umat Islam"[9]. Titik tekan dari pendidikan Islam adalah menyiapkan manusia memiliki keimanan, memiliki akhlak mulia dan menjalankan ibdah sesuai dengan perintah Allah agar selamat di dunia dan pasca dunia.

Abuddin Nata menjelaskan bahwa tujuan pendidikan Islam memiliki ciri sebagai berikut: Mengarahkan manusia agar menjadi pemimpin dimuka bumi dengan sebaikbaiknya, yaitu melaksanakan tugas memakmurkan dan mengolah bumi sesuai dengan kehendak Tuhan, mengarahkan manusia agar seluruh pelaksanaan tugas kekhalifaannya 
dilaksanakan dalam rangka beribadah kepada Allah, mengarahkan manusia agar berakhlak mulia, membina dan mengarahkan potensi akal, jiwa dan jasmaninya sehingga ia memiliki ilmu, ahlak dan keterampilan serta mengarahkan manusia agar mencapai kebahagiaan dunia dan akhirat[9].

Berdasarkan uraian sebelumnya, maka yang dimaksud dengan tansformasi nilai pendidikan Islam anak dalam artikel ini adalah adalah penanaman sifat atau hal yang melekat pada pendidikan Islam yang digunakan sebagai dasar anak untuk mencapai tujuan hidup manusia yaitu mengabdi kepada Allah SWT. Nilai pendidikan Islam harus dibawa pada kepribadian anak lewat lembaga pendidikan. Nilai pendidikan dalam kegiatan pendidikan dan pembimbingan menjadi bagian penting. Mujib menjelaskan dalam Islam terdapat nilai-nilai dasar yang menjadi pedoman dalam pendidikan Islam, yaitu: a) I'tiqadiyyah, berkaitan dengan pendidikan keimanan, seperti percaya kepada Allah, malaikat, rasul, kitab, hari akhir dan takdir, yang bertujuan untuk menata kepercayaan individu. b) Khuluqiyah, berkaitan dengan pendidikan etika, yang bertujuan untuk membersihkan diri dari perilaku rendah dan menghiasi dari dengan perilaku terpuji. Dan c) Amaliyyah, berkaitan dengan pendidikan tingkah laku sehari-hari, baik berhubungan dengan `pendidikan ibadah dan pendidikan muamalah.

\section{METODE}

Penelitian ini berjenis kualitatif dengan deskriptif analitis. Peneliti sebagai instrumen untuk menjaring dan mengkategorisasikan data yang ditemukan. Informan dalam penelitian ini adalah kepala sekolah, guru-guru dan orang tua anak PAUD Sultan Qaimuddin Kendari. Data dalam penelitian ini diperoleh melalui wawancara mendalam dan dokumentasi yang berkaitan dengan pendidikan Islam pada anak di PAUD Sultan Qaimuddin Kendari. Peneliti melakukan pengumpulan, pengkatogorisasian, penyajian dan penyimpulan data penelitian. Lokus penelitian ini di PAUD Sultan Qaimuddin Kendari, yang dilaksanakan pada bulan Mei sampai Juli 2020. Untuk menjaga kesahihan data penelitian maka peneliti melakukan triangulasi untuk menghasilkan data-data penelitian yang baik.

\section{HASIL DAN PEMBAHASAN}

Sehubungan dengan standar isi tentang tingkat capaian perkembangan anak, Pemerintah memberikan standar tingkat pencapaian perkembangan nilai agama dan moral pada anak usia dini sebagai berikut:

Tabel 1. Tingkat Pencapaian Perkembangan Nilai Agama dan Moral Anak Usia Dini (Lampiran Permendikbud No. 137 Tahun 2014)

\begin{tabular}{cll}
\hline Usia & \multicolumn{2}{c}{ Tingkat Pencapaian Perkembangan } \\
\hline 2 s/d 3 tahun & 1. $\begin{array}{l}\text { Mulai meniru gerakan berdoa/sembahyang } \\
\text { sesuain dengan agama masing-masing. }\end{array}$ \\
& $\begin{array}{l}\text { 2. Mulai meniru doa-doa pendek. } \\
\text { 3. Mulai memahami kapan mengucapkan salam, } \\
\text { terimakasih, maaf, dan sebagainya. }\end{array}$
\end{tabular}




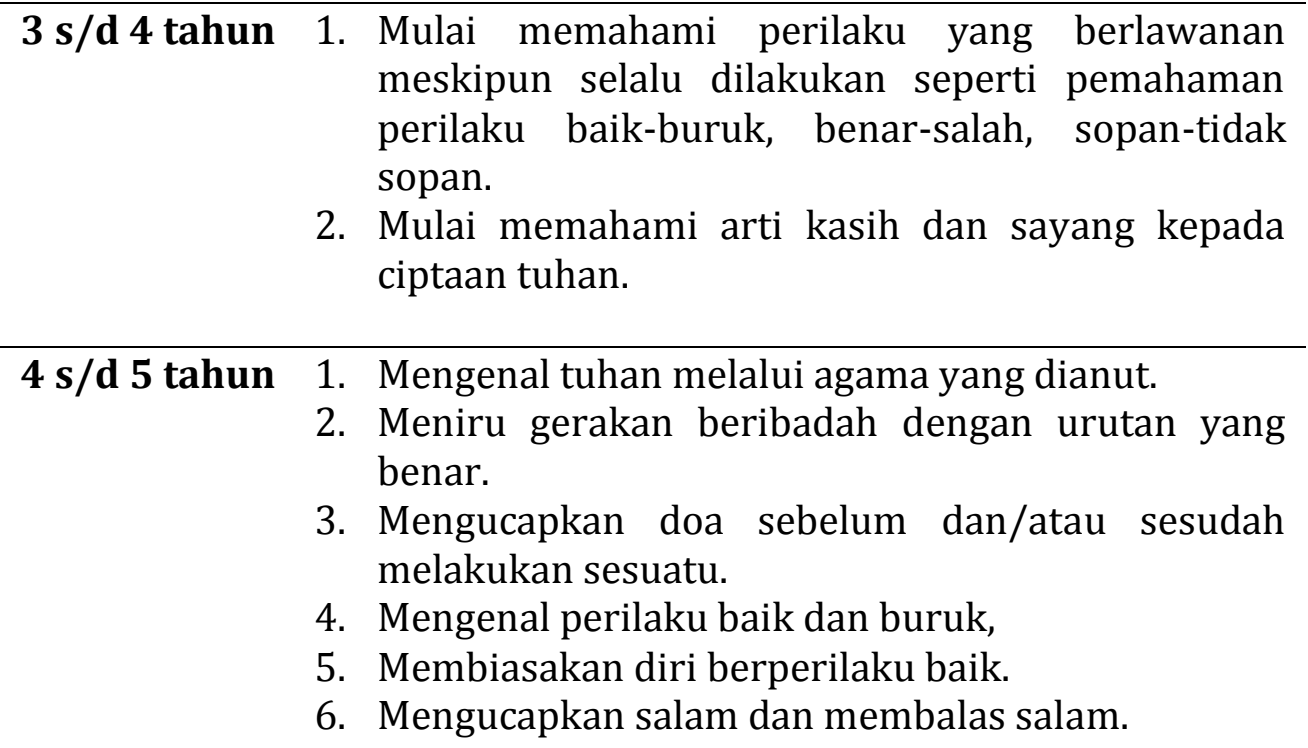
5 s/d 6 tahun 1. Mengenal agama yang dianut.
2. Membiasakan diri beribadah.
3. Memahami perilaku mulia (jujur, penolong, sopan, hormat).
4. Membedakan perilaku baik buruk.
5. Mengenal ritual dan hari besar agama.
6. Menghormati agama orang lain.

Hubungannnya dengan tabel di atas PAUD Sultan Qaimuddin Kendari mengelenggarakan pendidikan anak berusia 4 sampai dengan 6 tahun. Jika dihubungkan dengan standar tingkat pencapaian perkembangan nilai agama dan moral pada usia anak $4 \mathrm{~s} / \mathrm{d} 5$ tahun maka paling tidak kegiatan-kegiatan yang dilakukan adalah mengenal tuhan melalui agama yang dianut, meniru gerakan beribadah, mengucapkan doa sebelum dan/atau sesudah melakukan sesuatu, mengenal perilaku baik dan buruk, membiasakan diri berperilaku baik, mengucapkan salam dan membalas salam. Selanjutnya untuk usia 5 s/d 6 tahun kegiatan transformasi nilai pendidikan Islam adalah mengenal agama yang dianut, membiasakan diri beribadah, memahami perilaku mulia (jujur, penolong, sopan, hormat), membedakan perilaku baik buruk, mengenal ritual dan hari besar agama, dan menghormati agama orang lain. Dijelaskan oleh Ibnu Sina bahwa di usia anak (usia 3-5 tahun perlu diberikan mata pelajaran olah raga, budi pekerti, kebersihan, seni suara, dan kesenian[10].

Dalam pelaksanaan transformasi nilai pendidikan Islam di PAUD Sultan Qaimuddin Kendari terdapat nilai-nilai dasar yang menjadi pedoman dalam pendidikan Islam, yaitu: a) I'tiqadiyyah, berkaitan dengan pendidikan keimanan, seperti percaya kepada Allah, malaikat, rasul, kitab, hari akhir dan takdir, yang bertujuan untuk menata kepercayaan individu. b) Khuluqiyah, berkaitan dengan pendidikan etika, yang bertujuan untuk membersihkan diri dari perilaku rendah dan menghiasi dari dengan perilaku terpuji. Dan c) Amaliyyah, berkaitan dengan pendidikan tingkah laku sehari-hari, baik berhubungan dengan ’pendidikan ibadah, seperti yang dijelaskan di bawah ini. 


\section{Nilai Aqidah}

Pendidikan keimanan harus diajarkan pada anak sejak dini, seiring dengan pertumbuhan kepribadianya. Nilai-nilai aqidah/keimanan wajib diperkenalkan pada anak dengan cara sebagai berikut: 1) Memperkenalkan nama Allah SWT dan Rasul-Nya, 2) Memberikan gambaran tentang siapa pencipta alam raya ini melaui kisah-kisah teladan, dan 3) Memperkenalkan ke-Maha-Agungan Allah SWT[11]. Berkaitan dengan kegiatan pembinaan pendidikan Islam di PAUD, terdapat nilai-nilai aqidah di dalamnya. Adapun nilai-nilai pendidikan terlihat pada kegiatan sebagai berikut:

\section{a. Pembiasaan Kalimat Istighfar}

Pada masa pandemi covid 19 PAUD menyelenggerakan pendidikan dengan media online (whatsapp group bersama orang tua anak). Materi penanaman nilai pendidikan Islam tetap diberikan. Materi yang diberikan salah satunya membiasakan Anak PAUD sultan Qaimuddin dalam masa pandemi covid 19 melafalkan kalimat istighfar. Kalimat istighfar yang ditujukan kepada anak-anak أستغفرالله yang PAUD agar mereka memiliki pengetahuan untuk beraqidah. Kalimat Artinya: Aku memohon ampun pada Allah. Kalimat istighfar ini dijadikan kebiasaan agar anak kelak terbiasa dengan ucapan-ucapan yang baik. Ucapan yang baik merupakan perintah Islam, sebagaimana hadits Rasulullah SAW "barangsiapa yang beriman kepada Allah dan hari akhir hendaklah ia berkata yang baik. Dengan menjadikan istighfar sebagai kebiasaan, maka anak memiliki pengetahuan atau pengalaman keislaman sejak dini.

\section{b. Pembiasaan Pengucapan Dua Kalimat Syahadat}

Selain kalimat istighfar anak PAUD Sultan Qaimuddin Kendari dibekali dengan pembiasaan mengucapkan dua kalimat syahadat. Kalimat syahadat adalah ucapan: Asyhadu an Laa Ilaaha Illallah Wa Asyhadu Anna Muhammadan Rasuulullah." Artinya Saya bersaksi bahwa tiada tuhan selain Allah dan Muhammad adalah utusan Allah. Kalimat ini adalah kalimat tauhid yang diperkenalkan kepada anak sejak dini. Kalimat ini merupakan ikatan Aqidah yang dimaknai sebagai keimanan kepada Allah SWT. Sebagaimana iman merupakan kepercayaan yang terhujam ke dalam hati dengan penuh keyakinan, tak ada keraguan serta mempengaruhi orientasi kehidupan, sikap dan aktivitas keseharian[12]. Pembimbingan terhadap anak usia dini harus terus dilakukan sejak dini, khususnya untuk menumbuhkan nilai-nilai agama anak. Sunarta menjelaskan bimbingan terhadap anak merupakan proses memberikan bantuan kepada anak yang dilakukan secara berkesinambungan supaya individu tersebut dapat memahami dirinya sehingga ia sanggup mengarahkan diri dan dapat bertindak wajar sesuai dengan tuntutan dan keadaan keluarga serta masyarakat[13]. Anak dan keluarga terus dibimbing agar menemukan jati diri dan integritasnya sebagaimana pesan agama dalam Q.S At Tahrim (66): 6 Hai orang-orang yang beriman, jagalah dirimu dan keluargamu dari api neraka yang bahan bakarnya adalah manusia dan batu". Pesan tuhan dalam ayat ini mengingatkan dan mengharuskan manusia untuk selalu menjaga dan mengoptimalkan aspek-aspek perkembangan dan pertumbuhan serta lingkungan yang mengitarinya. 


\section{Nilai Amaliyah}

Nilai Amaliyyah, merupakan nilai yang berhubungan dengan kegiatan atau tingkah laku sehari-hari, baik berhubungan dengan pendidikan ibadah maupun muamalah. Adapun aktifitas nilai amaliyah yang diterapkan anak PAUD Siltan Qaimuddin Kendari pada masa pandemi covid 19 adalah sebagai berikut:

\section{a. Membiasakan Berdoa Sebelum dan Sesudah Beraktivitas}

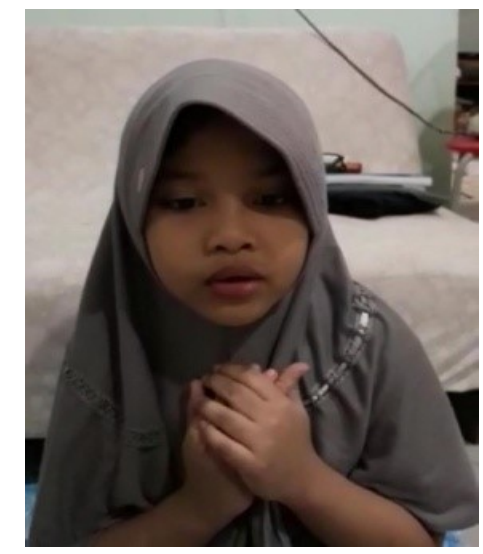

\section{Gambar 1. Kegiatan Berdoa Anak PAUD}

Gambar di atas adalah kegiatan anak membaca doa sebelum dan sesudah makan. Kegiatan ini dirancang oleh guru lewat bimbingan orang tua di rumah. Orang tua menjadi contoh bagi anak di rumah dan anak mengikuti dan mencontohi orang tuanya. Syaodih menjelaskan bahwa perkembangan nilai-nilai agama anak usia dini lebih bersifat imitasi yaitu menirukan sikap, cara pandang serta tingkah laku orang lain, anak bersikap inernalisasi yakni anak sudah mulai bergaul dengan lingkungan sosialnya dan mulai terpengaruh dengan keadaan di lingkungan tersebut[14]. Anak sejak dini harus diajarkan kegiatan-kegiatan keagamaan agar mereka tumbuh dengan budaya agamis. Wardani menjelaskan anak usia dini merupakan usia masa keemasan, maka anak harus diberikan latihan-latihan keagamaan melalui kegiatan berdoa, beribadah serta berperilaku sesuai ajaran agama, sehingga diharapkan anak akan menjadi taat beribadah terhadap ajaran agamanya. Apabila latihan itu dilalaikan sejak kecil atau dengan cara yang kurang tepat, maka ketika mereka menginjak usia dewasa nanti tidak akan memiliki kepedulian yang tinggi pada kehidupan beragama dalam kesehariannya[15]. Tujuan pendidikan anak sejak dini bukan hanya meliputi ranah pengetahuan dan keterampilan, namun lebih dari itu untuk ranah sikap, kepribadian dan moral. Melalui pendidikan moral dapat dicapai tujuan pendidikan yang menghasilkan peserta didik yang bermoral dalam pengetahuan, keterampilan, dan sikapnya. Guru sebagai penaggungjawab pelaksanaan pendidikan di sekolah diharapkan dapat melaksanakan pendidikan moral kepada anak, baik melalui interaksi guru dengan peserta didik, karena sebagai model langsung, maupun melalui materi-materi yang disampaikan guru dalam proses pembelajaran. Media pembelajaran yang digunakan dalam pendidikan juga diharapkan dapat membantu terlaksananya pendidikan moral pada anak sejak dini[16]. 


\section{b. Membiasakan Pola Hidup Bersih dan Sehat}

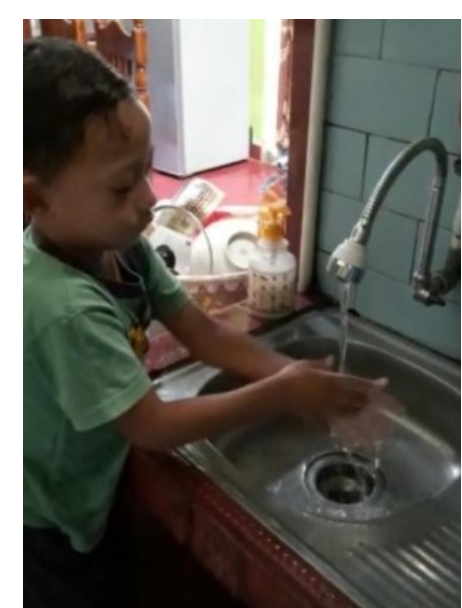

Gambar 2. Anak PAUD Mencuci Tangan

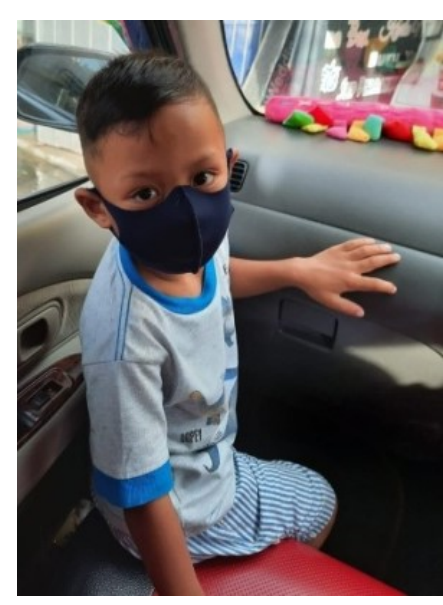

Gambar 3. Anak PAUD Memakai Masker

Pada masa pandemi covid 19 anak PAUD Sultan Qaimuddin Kendari juga dibekali dengan pengetahuan protokol kesehatan yaitu: membiasakan mencuci tangan dengan sabun, memakai hand sanitizer, dan menggunakan masker. Perilaku hidup bersih dan sehat merupakan anjuran untuk anak usia dini dimasa pandemi, apalagi didukung orang tua sebagai teladan anak. Seperti yang dijelaskan oleh Anhusadar bahwa lingkungan keluarga terbentuk rutinitas dan kebiasaan yang akan menjadi karakter yang baik dalam peningkatan derajat kesehatan. Budaya sehat akan terbentuk pada setiap individu di dalam keluarga. Orang tua setidaknya memberikan contoh nyata dalam melaksanakan perilaku ini kepada putra-putrinya. Sehingga anak-anak akan meniru dan ikut melaksanakan perilaku hidup bersih dan sehat ini dengan semangat, didampingi para orang tua yang peduli dengan anaknya[17].

Materi pola hidup bersih dan sehat menghadapi masa pandemi covid 19 merupakan materi tambahan pada kondisi pandemi saat ini khususnya untuk kegiatan memakai hand sanitizer dan memakai masker. Kegiatan mencuci tangan, menggunakan hand sanitizer dan memakai masker merupakan kebiasaan pola hidup bersih dan sehat (Wawancara, Asnawati, 2020). Dalam aktivitas tersebut di atas terdapat nilai-nilai pendidikan Islam. Sebagaimana pesan nabi Muhammad SAW "kebersihan dan kesucian merupakan bagian dari iman". Jelas bahwa transformasi nilai-nilai pendidikan Islam tetap ditanamkan pada anak walaupun dimasa pandemi covid $19 \mathrm{ini}$.

Posisi pendidikan anak usia dini sangat penting dalam meletakkan dasar-dasar keagamaan. Menumbuh kembangkannya, dan menjadi motivasi spiritual sehingga menjadi dasar yang kokoh dan sangat penting baik untuk melanjutkan pada jenjang pendidikan sekolah Dasar maupun sebagai modal awal yang baik guna menghadapi kehidupan yang akan datang[18]. Dalam masa pandemi covid 19 ini peran keluarga atau orang tua sangat besar dalam mengoptimalisasikan tumbuh kembang anak. Keluarga adalah pendidikan yang pertama dan terpenting, oleh karena sejak timbulnya adat kemanusiaan hingga kini, hidup keluarga itu selalu mempengaruhi pertumbuhan budi pekerti tiap-tiap manusia[19]. Pendidikan dalam latar keluarga memberi pengalaman 
pertama yang merupakan faktor penting dalam perkembangan nilai agama dan moral anak.

Oleh karena itu pada masa pembelajaran di rumah sekarang ini perlu kerjasama yang baik antara orang tua dan guru sebagai pendidik yang memengaruhi tingkah laku dan keperibadian anak harus didorong untuk menciptakan dan menggunakan keteladanan dan pembiasaan yang baik serta terencana bagi pembentukan sikap dan penanaman nilai-nilai ajaran agama. Sebab anak sebagai rahmat dan amanah dari allah harus dirawat, diasuh dan dididik sesuai dengan tujuan islam[20]. Pembelajaran agama Islam memiliki pengaruh terhadap perkembangan moral anak. Pembelajaran Islam adalah suatu proses terjadinya interaksi antara peserta didik dan pendidik dalam upaya memberikan pengajaran dan bimbingan agama sesuai dengan tuntunan ajaran agama islam yang bersumber dari Al- Quran dan As-Sunnah[21]. Tafsir yang memberikan titik tekan bahwa Perhatian orang tua diharapkan selalu menyediakan waktu yang cukup serta membina komunikasi antara orang tua dengan anak, anak dengan guru demi menciptakan keharmonisan dan keakraban diantara anggota keluarga[22]. Jika kolaborasi dan kedekatan antara anak dan orang tua semakin akrab, maka akan tercipta kondisi yang lebih harmonis dalam keluarga. Orang tua menjadi patron bagi anakanaknya dan anak akan meneladani nilai kebaikan dari orang tuanya.

\section{KESIMPULAN (12 PT. CAMBRIA BOLD)}

Berdasarkan penjelasan sebelumnya dapat disimpulkan sebagai berikut: 1) kegiatan transformasi nilai pendidikan Islam anak masih dilakukan dimasa pandemi covid 19, walaupun tidak semua nilai agama ditanamkan pada anak. 2) Proses transformasi nilai pendidikan Islam anak dilakukan oleh guru bersama orang tua melalui komunikasi online (whatsapp) mengalami hambatan, tidak seperti aktifitas tatap muka. 3) Nilai pendidikan Islam yang ditrasformasikan pada anak adalah nilai aqidah berupa mengucapkan kalimat-kalimat istighfar dan membiasakan melafalkan syahadat. Selanjutnya nilai amaliyah yaitu membiasakan membaca doa-doa harian dan membiasakan pola hidup bersih dan sehat dengan mencuci tangan dan memakai masker.

\section{PENGHARGAAN (12 PT. CAMBRIA BOLD)}

Penulis bertutur kasih yang tinggi kepada mereka yang telah berbagi informasi, sehingga dengan informasi-informasi tersebut penulis bisa menyatukannya menjadi sebuah karya yang cacat kesempurnaan ini. Mereka adalah Yayasan Sultan Qaimuddin Kendari, kepala sekolah, guru, dan orang tua. Selanjutnya terimakasih pula kepada pengelola Murhum: Jurnal Pendidikan Anak Usia Dini yang telah menjadikan tulisan ini menjadi nyata dihadapan pembaca. 


\section{REFERENSI}

[1] M. Pendidikan and K. R. Indonesia, "Permendikbud Nomor 137 Tahun 2014 Tentang Standar Nasional Pendidikan Anak Usia Dini." Diunduh, 2018.

[2] H. Wulandari and E. Purwanta, "Pencapaian Perkembangan Anak Usia Dini di TK selama Pembelajaran Daring saat Pandemi Covid-19," J. Obs. J. Pendidik. Anak Usia Dini, vol. 5, no. 1, pp. 452-462, 2021.

[3] L. Hewi and L. Asnawati, "Strategi Pendidik Anak Usia Dini Era Covid-19 dalam Menumbuhkan Kemampuan Berfikir Logis," J. Obs. J. Pendidik. Anak Usia Dini, vol. 5, no. 1, p. 158, May 2020.

[4] E. Kurniati, D. K. Nur Alfaeni, and F. Andriani, "Analisis Peran Orang Tua dalam Mendampingi Anak di Masa Pandemi Covid-19," J. Obs. J. Pendidik. Anak Usia Dini, vol. 5, no. 1, p. 241, May 2020.

[5] H. M. C. Thoha, Kapita selekta pendidikan Islam. Pustaka Pelajar, 1996.

[6] S. Adisusilo, "Pembelajaran nilai karakter: Konstruktivisme dan VCT sebagai inovasi pendekatan pembelajaran afektif," Jakarta PT Raja Graf. Persada, 2012.

[7] A. Azra, Pendidikan Islam: tradisi dan modernisasi menuju milenium baru. Logos Wacana Ilmu, 1999.

[8] H. Langgulung, "Beberapa Pemikiran Kepemimpinan Pendidikan Islam,” Bandung al-Ma'arif, Cet. II, 1998.

[9] A. Nata and Fauzan, Filsafat Pendidikan Islam. Gaya Media Pratama, 2005.

[10] A. T. A. Putra, "Pemikiran Filosofis Pendidikan Ibnu Sina Dan Implikasinya Pada Pendidikan Islam Kontemporer," LITERASI (Jurnal Ilmu Pendidikan), vol. 6, no. 2, p. 191, Aug. 2016.

[11] H. M. N. Abdul, “Anak Shaleh Dambaan Keluarga, cet. ke-3," Yogyakarta: Mitra Pustaka, 2003.

[12] Y. Qardhawi, “Merasa Kehadiran Tuhan," Yokyakarta: Mitra Pusaka, 2000.

[13] Sunarta, Pengembangan Peserta didik. Jakarta: P2MTK, 1994.

[14] E. Purba, A. Yusuf, and I. Astuti, "Peningkatan Nilai-Nilai Agama dan Moral Melalui Metode Bercerita Pada Anak Usia 4-5 Tahun," Tanjungpura University, 2013.

[15] D. M. Kusuma Wardani and M.- Brantasari, "Peningkatan Nilai-Nilai Agama Dan Moral Pada Anak Kelompok B Beragama Hindu Melalui Metode Bercerita Di TK Tunas Bangsa Tenggarong Seberang Tahun Pelajaran 2018/2019," J. Warn. Pendidik. dan Pembelajaran Anak Usia Dini, vol. 4, no. 2, pp. 97-109, Nov. 2019.

[16] M. Khaironi, "Pendidikan Moral Pada Anak Usia Dini," J. Golden Age, vol. 1, no. 01, pp. 1-15, 2017.

[17] Anhusadar, Laode, and Islamiyah Islamiyah. "Penerapan Perilaku Hidup Bersih dan Sehat Anak Usia Dini di Tengah Pandemi Covid 19." Jurnal Obsesi: Jurnal Pendidikan Anak Usia Dini 5.1 (2020): 463-475.

[18] R. Ananda, "Implementasi Nilai-nilai Moral dan Agama pada Anak Usia Dini," J. Obs. J. Pendidik. Anak Usia Dini, vol. 1, no. 1, p. 19, Jun. 2017.

[19] Zahra Idris, Dasar-Dasar Kependidikan. Bandung: Aksara, 1982.

[20] A. Abdurrahman, "Upaya Meningkatkan Perkembangan Nilai Agama dan Moral Melalui Metode Keteladanan pada Anak Usia Dini," Realita J. Bimbing. dan Konseling, vol. 4, no. 7, 2019.

[21] R. Fitri and S. Satrianis, "Pengaruh Pembelajaran Agama Islam Terhadap Perkembangan Moral Anak Usia 5-6 Tahun Di TK Al-hasanah Kecamatan Rumbai Pesisir," PAUD Lect. J. Pendidik. Anak Usia Dini, vol. 1, no. 2, pp. 144-158, Apr. 2018. 
Aris Try Andreas Putra 1, Sufiani 2, dan Jahada 3

[22] A. Tafsir, "Pendidikan Agama dalam Keluarga, Bandung: PT," Remaja Rosda Karya, 2001. 